\title{
COMPARATIVE STUDY ON THE BIOSORPTION AND DESORPTION OF THREE SELECTED TOXIC HEAVY METALS BY SOME MICROALGAE
}

\author{
Ahmed A. El-Awamri ${ }^{1}$, Hesham M. Abd El Fatah ${ }^{1 *}$, Sabah A. Badr ${ }^{2}$, \\ Azza A. Ashmawy ${ }^{2}$, Iman Y. El-Sherif ${ }^{2}$ and Reda M. Moghazy ${ }^{2}$ \\ 1- Botany Department, Faculty of Science, Ain Shams University, Cairo, Egypt. \\ 2- Water Pollution Department, National Research Centre, Dokki, Cairo, Egypt
}

\begin{abstract}
Biosorption has emerged as a cost-effective and efficient alternative technology for removal of heavy metals which produce adverse health effects on humans and living organisms. In the present study the biosorption and desorption of cadmium, lead and zinc by Chlamydomonas variabilis, Anabaena constricta and Nitzschia linearis were evaluated. Algal species were isolated and cultivated on a large scale to get an intensive biomass sufficient for metal binding experiments. The experimental adsorption data were fitted to the Langmuir and Freundlich adsorption model. Characterization of the metal-loaded biosorbent by FTIR spectrum, TEM and EDX analysis confirmed that the metal ions can bind to anionic groups due to electrostatic attraction and sorption capacity is strongly influenced from the type and number of functional groups of the biosorbent. The maximum efficiencies of $\mathrm{Cd}, \mathrm{Pb}$ and $\mathrm{Zn}$ removal using C. variabilis were $97.9 \%$, $96.1 \%$ and $96.1 \%$ for oven dried biomass and $96.3 \%, 94.2 \%$ and $94.1 \%$ for activated biomass. For dried and activated biomass prepared of A. constricta the maximum percentage of removal of heavy metals were $95.1 \%, 93.7 \%$, and $93.1 \%$ and $94.3 \%, 96.1 \%$ and $94.1 \%$. The maximum removals by $N$. linearis were $95.5 \%, 96.6 \%, 94.8 \%$ for oven dried biomass and $93 \%, 94.5 \%$ and $93.8 \%$ for activated one respectively. There are no clear variations in biosorption of cadmium, lead and zinc by sun dried, oven dried and activated biomass of $C$. variabilis, A. constricta and $N$. linearis. It is better to use sun dried algae as low cost biosorbent for metals removal.
\end{abstract}

Keywords: Biosorption, Cadmium, Lead, Zinc, Chlamydomonas variabilis, Anabaena constricta and Nitzschia linearis.

\section{Introduction}

Heavy metal pollution is a world-wide environmental problem especially in developing countries. The heavy metal contamination arising from the discharge of untreated aqueous streams, arising from the discharge of untreated metal containing effluent into water bodies is one of the most important environmental issues (Hawari and Mulligan, 2006). Their presence in aquatic ecosystem cause 
harmful effects to living organisms (Wang et al., 2006). Various industries discharge heavy metals into environment such as mining, leaching, surface finishing industry, energy and fuel production, fertilizer and pesticide industry, electroplating, leatherworking, electrical appliance manufacturing. Presence of heavy metals and their compounds, even in small amounts, in industrial wastewater is very dangerous and must be removed (Sari and Tuzen, 2008). Cadmium, Lead and Zinc are kinds of heavy metals of concern as they are toxic metals (Wang and Chen, 2009).

Numerous studies have been carried out to find the most effective and low cost methods for the removal of heavy metals (Babel and Kurniawan, 2003; Yadanaparthi et al., 2009). Biosorption has emerged as a cost-effective and efficient alternative treatment technology for removal of heavy metals. It has been employed as an alternative method for removal of toxic metal ions from dilute aqueous solutions and industrial effluents (Sethunathan et al., 2005; Karthikeyan et al., 2007; Vieira et al., 2007; Anyurt et al., 2009; Atolaiye et al., 2009).

Different types of biomass in non-living form have been studied for their heavy metal uptake capacities (Gupta et al., 2006; Gupta and Rastogi, 2008). Microorganisms are in fact considered intrinsically more efficient in the bioaccumulation of heavy metals when exposed to low concentrations in their surrounding aqueous environment (Barange et al., 2014). Of the many types of biosorbents recently investigated for their ability to sequester heavy metals, microalgal biomass has proven to be highly effective as well as reliable and predictable in the removal of heavy metals from aqueous solutions (Priyadarshani et al., 2011).

The mechanism of binding metal ions by algal biomass may depend on the species and ionic charges of metal ion, the algal organism and the chemical composition of the metal ion solution. The identification of functional groups of algae is very important for understanding the mechanism. Cell walls of algae consist of functional groups, such as amino, carboxyl, thiol, phosphoric, and sulphydryl, which are responsible for binding of metal ions (Yalçin et al., 2010; Yang et al., 2010; Christobel and Lipton, 2015). Algal cell wall has very high metal-binding capacities as proteins, carbohydrates and lipids present in cell walls and membranes could react with metallic species (Monteiro et al., 2012). Their intensity depends largely on the kind, number, affinity, and distribution on the cell wall. Therefore, to use algal biomass effectively for water purification, it is 
important to understand the chemical nature of the metal binding process (Duygu and Bikem, 2013). Metal biosorption may be enhanced by heat or chemical sterilization or by degradation of cell wall and theses would offer a larger available surface area and expose the intracellular components and more surface binding sites because of the destruction of the cell membranes (Wang and Chen, 2009).

The aim of this study is to carry out a comparative biosorption and desorption of cadmium, lead and zinc by Chlamydomonas variabilis, Anabaena constricta and Nitzschia linearis in order to evaluate the most efficient one in removal of these heavy metals.

\section{Materials and Methods}

\section{A) Preparation of Biosorbent:}

Three algal species (Chlamydomonas variabilis Dangeard, Anabaena constricta (Szafer) Geitler and Nitzschia linearis W. Smith) were isolated from the Nile River. Algal identification has been done according to the keys of identification (Geitler, 1932; Hustedt, 1976; Komárek and Fott, 1983). Algal species were cultivated using BG11 medium and modified BG11 for green alga and blue green one respectively (Stanier $\boldsymbol{e t}$ al., 1971) and diatom medium for diatom species (Cohn et al., 2003). The cultivation was performed on a large scale to get an intensive biomass production sufficient for metal binding experiments.

B) Structural elucidation of Biosorbent using FTIR, TEM and EDX analysis:

The characterizations of algal biosorbents were investigated by using: Fourier Transform Infra-Red Spectroscopy (FT-IR) (Guibaud et al., 2003), Transmission Electron Microscope (TEM) (Jeol Electron microscope JEM-2100) and Energy Dispersive X-ray microanalysis (EDX) (Figueira et al., 1999).

\section{C) Sorption experiment:}

The yielded biomasses of the three microalgae were sun dried and others were oven dried, the biomasses were grinded on an igate stone pestle mortar to obtain a homogeneous and a powdered dried algal biomass. The oven dried biomasses were then treated by $\mathrm{Ca} \mathrm{Cl}_{2}, \mathrm{Na}_{2} \mathrm{CO}_{3}, \mathrm{Na}_{2} \mathrm{SO}_{4}$ and $\mathrm{H}_{2} \mathrm{SO}_{4}$ to get activated algal biosorbents. These biosorbents subjected to patch removal experiments under controlled optimum conditions of $\mathrm{pH}$ range 4-5, $150 \mathrm{~min}$ 
contact time, and $2 \mathrm{~g} / \mathrm{L}$ biosorbents. The biosorbents dose were conducted in metal solutions with different concentrations of $(10,20,30,40,50$ and 60$) \mathrm{mg} / \mathrm{L}$.

\section{D) Sorption isotherm experiment:}

The relationship between metal biosorption capacity and metal concentration at equilibrium has been described by two-parameter sorption isotherm models:

i) Langmuir isotherm:

$$
\frac{C_{e}}{q_{e}}=\frac{1}{b q_{\max }}+\frac{C_{e}}{q_{\max }}
$$

Where $\mathrm{q}_{\mathrm{e}}$ is the amount of metal ions sorbed per unit mass onto dried algae $(\mathrm{mg} / \mathrm{g}), \mathrm{q}_{\max }$ is maximum adsorption capacity at complete monolayer coverage $(\mathrm{mg} / \mathrm{g})$; $\mathrm{b}$ is a Langmuir constant that relates to the heat of adsorption $(\mathrm{L} / \mathrm{mg})$.

ii) Freundlich isotherm:

\section{$\log q_{e}=\log k_{F}+1 / n \log C_{e}$}

Where $\mathrm{q}_{\mathrm{e}}$ is the equilibrium adsorption capacity, $(\mathrm{mg} / \mathrm{g}), \mathrm{C}_{\mathrm{e}}$ is the equilibrium concentration of metal ions in the solution $(\mathrm{mg} / \mathrm{L}) . \mathrm{k}_{\mathrm{F}}$ represents the adsorption capacity when metal ion equilibrium concentration equals to 1 $(\mathrm{mg} / \mathrm{g}), \mathrm{n}$ is the degree of dependence of adsorption with equilibrium concentration.

\section{E) Desorption Experiments:}

After the biosorption cycle the biosorbents were centrifuged and washed twice with distilled water and dried. The biosorbents were added to 50 $\mathrm{mL}$ of the desorption eluent $0.1 \mathrm{M} \mathrm{HNO}_{3}$. The biosorbents with eluent were left on the shaker at $150 \mathrm{rpm}$ for $150 \mathrm{~min}$., then the eluent was removed and the final ions concentration measured. Adsorption and desorption cycles are repeated to evaluate adsorption and desorption potential of the biosorbents to determine the availability of its reuse. 


\section{Results and Discussion}

\section{A) Characterizations of algal biosorbents}

\section{1- FT-IR Spectroscopy}

The FT-IR spectroscopy method was used to obtain information on the nature of possible interactions between several functional groups of different microalgae biomasses and the metal ions. The FT-IR spectra display number of absorption peaks, indicating the nature of oven dried and activated biomasses of isolated algae (Figs. 1, 2, and 3). The bands located at 3553 and $3409 \mathrm{~cm}^{-1}$ in both oven dried and activated biosorbents of the three isolated algae represent bonded $\mathrm{OH}$ of carboxylic groups on their surface. The bands at $3240 \mathrm{~cm}^{-1}$ representing stretching of $-\mathrm{NH}$ groups, while the band at 1541-1387 $\mathrm{cm}^{-1}$ representing stretching amide $(\mathrm{C}-\mathrm{N}$ and $\mathrm{N}-\mathrm{H})$ from proteins for the three isolates. Also the peaks located at $1637-1617 \mathrm{~cm}^{-1}$ are representing carbonyl group $\left(-\mathrm{HC}=\mathrm{O}, \mathrm{R}_{2}\right.$ $\mathrm{C}=\mathrm{O}$ ) stretching for the three isolates. Aliphatic $\mathrm{C}-\mathrm{H}$ group is represented by the bands at 2960-2920 and $2850 \mathrm{~cm}^{-1}$ for Chlamydomonas and by the bands at 2960 and 2850 for Anabaena and Nitzschia .The bands between 2366 and $2310 \mathrm{~cm}^{-1}$ could be assigned to the S-H stretching group for Anabaena and 2366-2028 S-H stretching group for Chlamydomonas. The bands between $2366-2317 \mathrm{~cm}^{-1}$ could be assigned to the $\mathrm{Si}-\mathrm{H}$ stretching of Silicon group for Nitzschia. Alkyne $\mathrm{C} \equiv \mathrm{C}$ group for Anabaena was represented by the bands between $2150-2028 \mathrm{~cm}^{-1}$. Bands between $2028 \mathrm{~cm}^{-1}, 1755 \mathrm{~cm}^{-1}$ correspond to the free $\mathrm{C}=\mathrm{O}$ for Nitzschia and Chlamydomonas respectively. These groups can be conjugated or nonconjugated to aromatic rings (Cesar and Marco, 2004). The vibrations observed at 466 and $1100 \mathrm{~cm}^{-1}$ correspond to asymmetric stretching modes of $\mathrm{Si}-\mathrm{O}-\mathrm{Si}$ bonds whilst the $\mathrm{M}-\mathrm{O}-\mathrm{Si}$ stretching vibration is indicated at $800 \mathrm{~cm}^{-1}$ for Nitzschia, Huang et al., (2007) and Sheng et al., (2009) found that, the peaks at 472 and $1095 \mathrm{~cm}-1$ may be attributed to the asymmetric stretching modes of $\mathrm{Si}$ $\mathrm{O}-\mathrm{Si}$ bonds, the peak at $800 \mathrm{~cm}-1$ may correspond to the stretching vibration of Al-O-Si. The band at $615 \mathrm{~cm}^{-1}$ representing $\mathrm{H}_{2} \mathrm{PO}_{4}{ }^{1-}$ or $\mathrm{PO}_{4}{ }^{3-}$ for the three isolated algae, also band at $466 \mathrm{~cm}^{-1}$ representing metal compounds for the three algae. Monteiro et al., (2012) stated that the microalgal cell wall consisted mainly of polysaccharides, proteins, and lipids, which offer several functional groups 


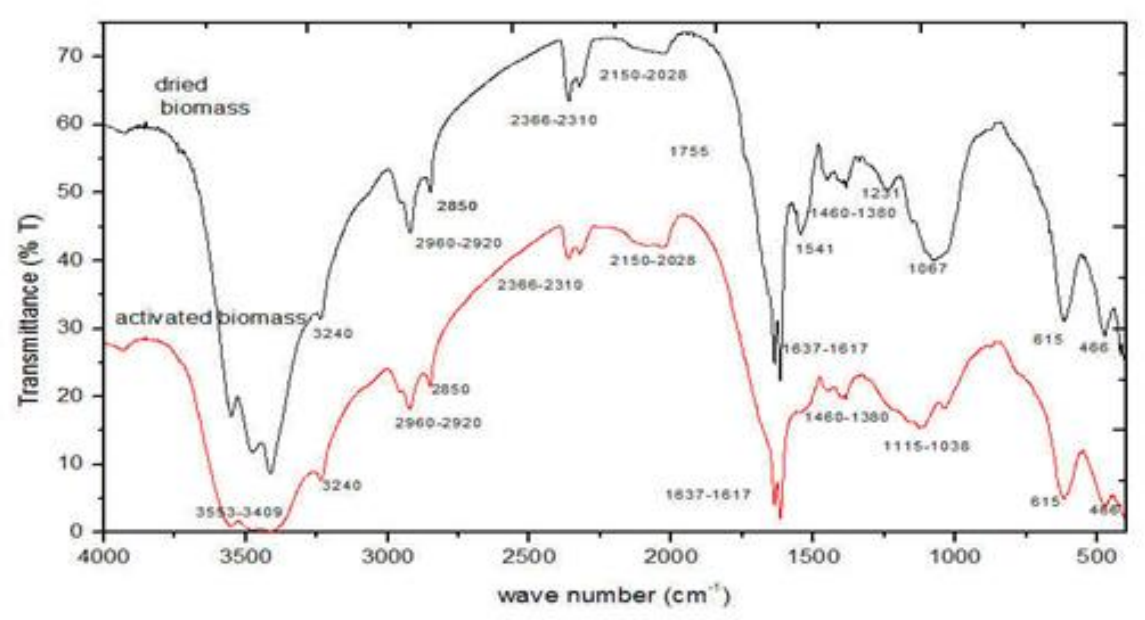

Fig. (1) FT-IR spectra of oven dried Chlamydomonas variabilis and its activated biomass

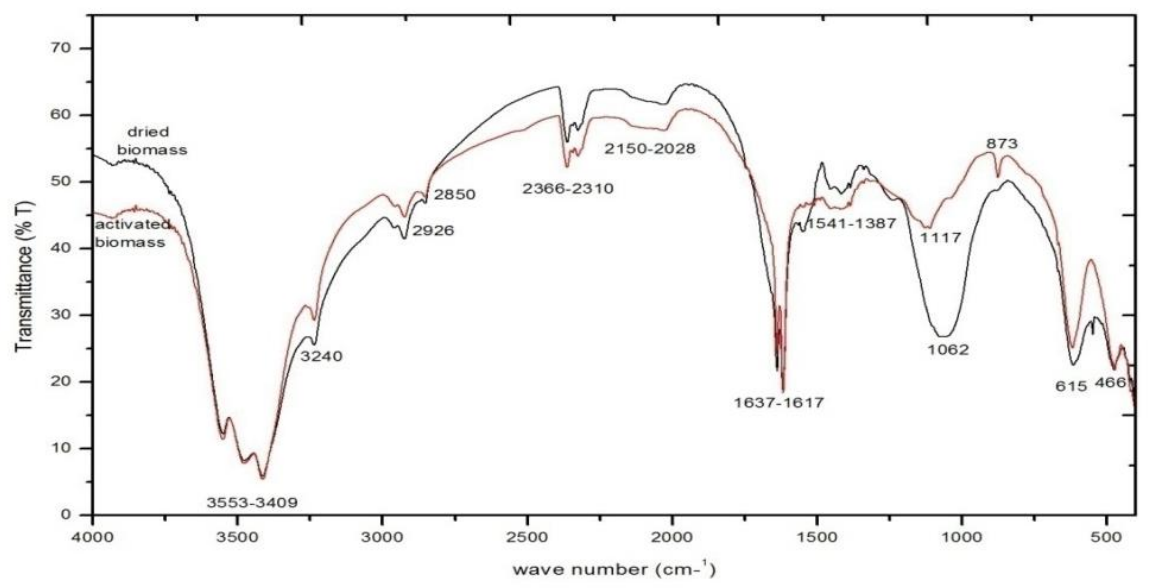

Fig. (2) FT-IR spectra of oven dried Anabaena constricta and its activated biomass 


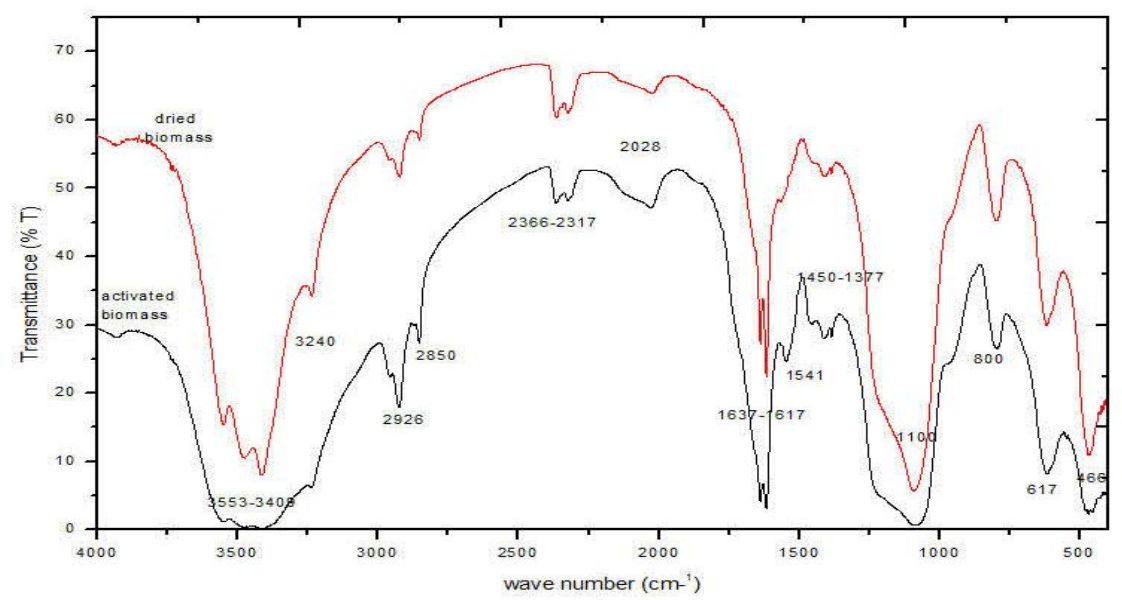

Fig. (3) FT-IR spectra of oven dried Nitzschia linearis and its activated biomass

(e.g., carboxyl,-COOH; hydroxyl, $-\mathrm{OH}$; phosphate, $-\mathrm{PO}_{3}$; amino,-- $\mathrm{NH} 2$; and sulfhydryl, $-\mathrm{SH}$ ) that confirm a net overall negative charge to the cell surface, and concomitantly a high binding affinity for metal cations via counter ion interactions. Also Duygu and Bikem (2013) stated that in Nitzschia closterium biomass carboxylate groups were mainly involved in coordination of bivalent ions, but also electron donors groups, such as amino, amide and hydroxyl groups, were likely to play a role in the sorption process. It has been well documented that these function groups located at cell wall could react with metallic species facilitating metal binding processes (Sharma et al., 2011; Chinedu et al., 2012; Bakatula et al., 2014; Bulgariu and Bulgariu, 2014; Kumar et al., 2015).

\section{2- Transmission Electron Microscope (TEM)}

The examination of the oven dried biomasses of isolated algae by (TEM) show the morphologic nature of the biomasses material of Chlamydomonas, Anabaena, and Nitzschia. The isolated algal biomasses can facilitate the sorption of metals by their irregular surfaces that contain fractions of nanopores and nanoparticles which have nanoscale measure ranged between 1$100 \mathrm{~nm}$. It has been monitoring the nanoscale structures in Chlamydomonas biomass ranged between 36-47 nm (Fig. 4), while in Anabaena were ranged 
between 23-51 nm (Fig. 5), and in Nitzschia were ranged between 4.7-120 nm (Fig. 6). The sheath or projection in Chlamydomonas might be one of the defense mechanism against metal ion toxicity and may not allow the metal ions to enter the algal cell since the functional chemical groups on the sheath would complex or chelate the metal ions (Staley, 1989). In the biomass of Nitzschia nanopores are distributed along the frustules shell wall in symmetric manner through the two silica valves and they will allow the free passage of molecules and ions in aqueous solutions.
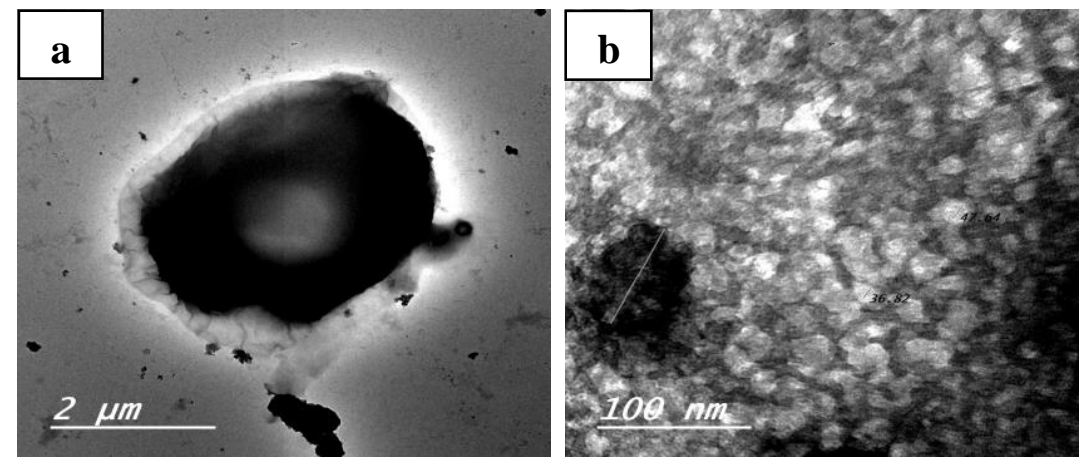

Fig. (4) TEM micrographs of oven dried biomass of Chlamydomonas variabilis showing: a- the cell with outer sheath, $b$ - nonporous and nanoparticles at nanoscale measure ranged between $(36-47 \mathrm{~nm})$.

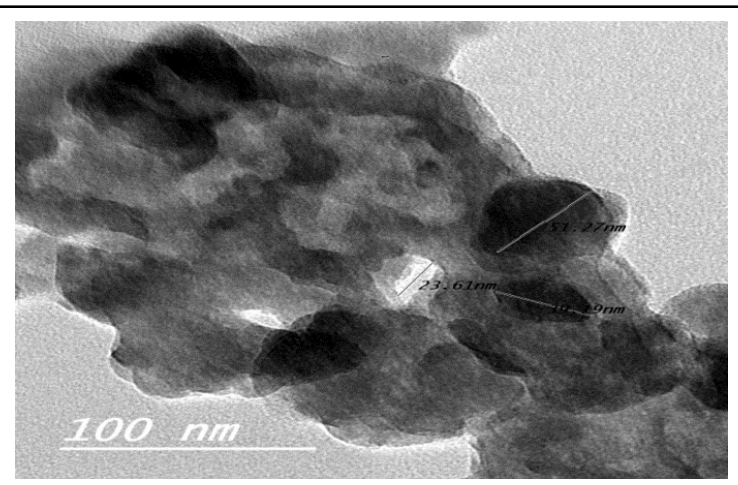

Fig. (5) TEM micrographs of oven dried biomass of Anabaena constricta showing irregular surface of the algal biomass, as well as nonporous and nanoparticles at nanoscale measure ranged between $(23-51 \mathrm{~nm})$ 

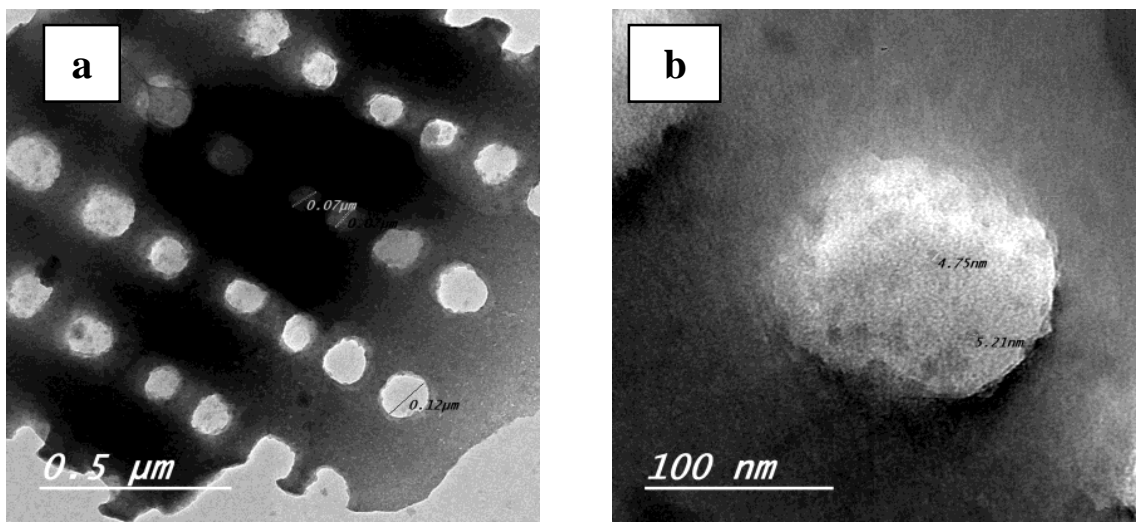

Fig. (6) TEM micrographs of oven dried biomass of Nitzschia linearis showing: a- symmetric form of nonporous, b- nanoscale measure of nanopores and nanoparticles ranged between $(4.7-120 \mathrm{~nm})$.

This finding was in agreements with Poulsen et al., (2007); Yu et al., 2012; Jeyakumar and Chandrasekaran, 2014. On the other hand Eggen (2012) reported that diatoms are known to have a high affinity towards a variety of dissolved trace elements and they will therefore exert a strong control on the transfer of heavy metals along the water column to the sediments. So, it can be concluded that the biomass material of the isolated algae has a morphological profile enable it to adsorb metal ions and these were similarly reported by ElSikaily et al., 2011. Grinding the algal cells offers a larger available surface area and exposes the intracellular components and more surface binding sites because of the destruction of the cell membranes (Errasquin and Vazquez, 2003).

\section{3- Energy Dispersive X-ray spectroscopy (EDX)}

The oven dried and activated biomasses of the three isolated algae were characterized and examined by using (EDX) to find out chemical composition. Carbon and oxygen were abundance components of oven dried and activated biomass of Chlamydomonas with percentages weight of $54.8 \% \mathrm{C}$ and $33.5 \% \mathrm{O}$ for dried biomass and $62.1 \% \mathrm{C}$ and $31.2 \% \mathrm{O}$ for activated biomass. Oxygen, carbon and nitrogen were the abundance components for Anabaena with percentage weight of $37.2 \% \mathrm{O}, 31.3 \% \mathrm{C}$ and $21.2 \% \mathrm{~N}$ for oven dried biomass and $37 \%$ O, $47.7 \% \mathrm{C}$ for activated biomass. But in case of Nitzschia oxygen, carbon 
and silica were the abundance components with percentages weight of $43 \% \mathrm{O}$, $29 \% \mathrm{C}$ and $21 \% \mathrm{Si}$ for oven dried biomass and $48 \%$ O, 29.3\% C, 24\% Si for activated biomass. The presences of these abundance components as the major groups in isolated algal biomasses are compatible with FT-IR data in which many functional groups have a role in metals uptake.

\section{B) Metal removal}

\section{Determination the optimum initial metals concentrations}

For sun dried biomass, in Chlamydomonas variabilis, it was found that the maximum percentages of removals for $\mathrm{Cd}, \mathrm{Pb}$, and $\mathrm{Zn}$ were $96.8 \%, 95.8 \%$, and $98.6 \%$ respectively. Anabaena constricta show maximum removals $95.1 \%$, $93.7 \%$, and $93.1 \%$ for $\mathrm{Cd}, \mathrm{Pb}$, and $\mathrm{Zn}$ respectively. The highest percentages of removals in Nitzschia linearis were $92.0 \%, 89.6 \%$, and $88.6 \%$ for $\mathrm{Cd}, \mathrm{Pb}$, and $\mathrm{Zn}$ respectively (Fig.7). These percentages of removals were obtained at initial metal concentrations 9.4, 9.6 and $8.8 \mathrm{mg} / \mathrm{L}$, for $\mathrm{Cd}, \mathrm{Pb}$ and $\mathrm{Zn}$, respectively. Romera et al., (2007) recorded that the optimum $\mathrm{pH}$ value for recovery of $\mathrm{Cd}$, $\mathrm{Ni}$ and $\mathrm{Zn}$ was 6 and the optimum sorption $\mathrm{pH}$ for $\mathrm{Cu}$ ranged from 4 to 5 and for $\mathrm{Pb}$ from 3 to 5 .

For the oven dried biomass (Fig.8), the maximum removals of $\mathrm{Cd}, \mathrm{Pb}$ and $\mathrm{Zn}$ by Chlamydomonas were $97.9 \%, 96.1 \%$ and $96.1 \%$ respectively. These percentages were reached at $9.8,9$ and $8.9 \mathrm{mg} / \mathrm{L}$ of $\mathrm{Cd}, \mathrm{Pb}$ and $\mathrm{Zn}$ respectively. For Anabaena $\mathrm{Cd}, \mathrm{Pb}$ and $\mathrm{Zn}$ the maximum removals accomplished at $97.5 \%$, $94.1 \%$ and $96.7 \%$ respectively; these removals were correlated with 9.5, 8.5 and $8.7 \mathrm{mg} / \mathrm{L}$ of $\mathrm{Cd}, \mathrm{Pb}$ and $\mathrm{Zn}$ ions respectively. Abdel-Aty et al., (2013) found that the biosorption of $\mathrm{Cd}$ and $\mathrm{Pb}$ by oven dried biomass of Anabaena sphaerica was achieved at $94.3 \%$ and $88.6 \%$ respectively. The maximum removals of $\mathrm{Cd}, \mathrm{Pb}$ and Zn by Nitzschia were $95.5 \%, 96.6 \%$ and $94.8 \%$ respectively, these removals were obtained at initial concentrations $9.3,9$ and $8.6 \mathrm{mg} / \mathrm{L}$ for $\mathrm{Cd}, \mathrm{Pb}$ and $\mathrm{Zn}$ ions respectively. Also the data show that percentage adsorption decreased with increase in initial concentration of the adsorbate (Abdel-Aty et al., 2013).

For activated biomass, in Chlamydomonas the maximum removals of $\mathrm{Cd}$, $\mathrm{Pb}$ and $\mathrm{Zn}$ ions were $96.3 \%, 94.2 \%$ and $94.1 \%$ respectively, with initial metal concentrations 9.6,9 and 9.3 mg/L for $\mathrm{Cd}, \mathrm{Pb}$ and $\mathrm{Zn}$ respectively. In Anabaena the maximum removals for $\mathrm{Cd}, \mathrm{Pb}$ and $\mathrm{Zn}$ were $94.6 \%, 96.1 \%$ and $94.2 \%$ respectively. 


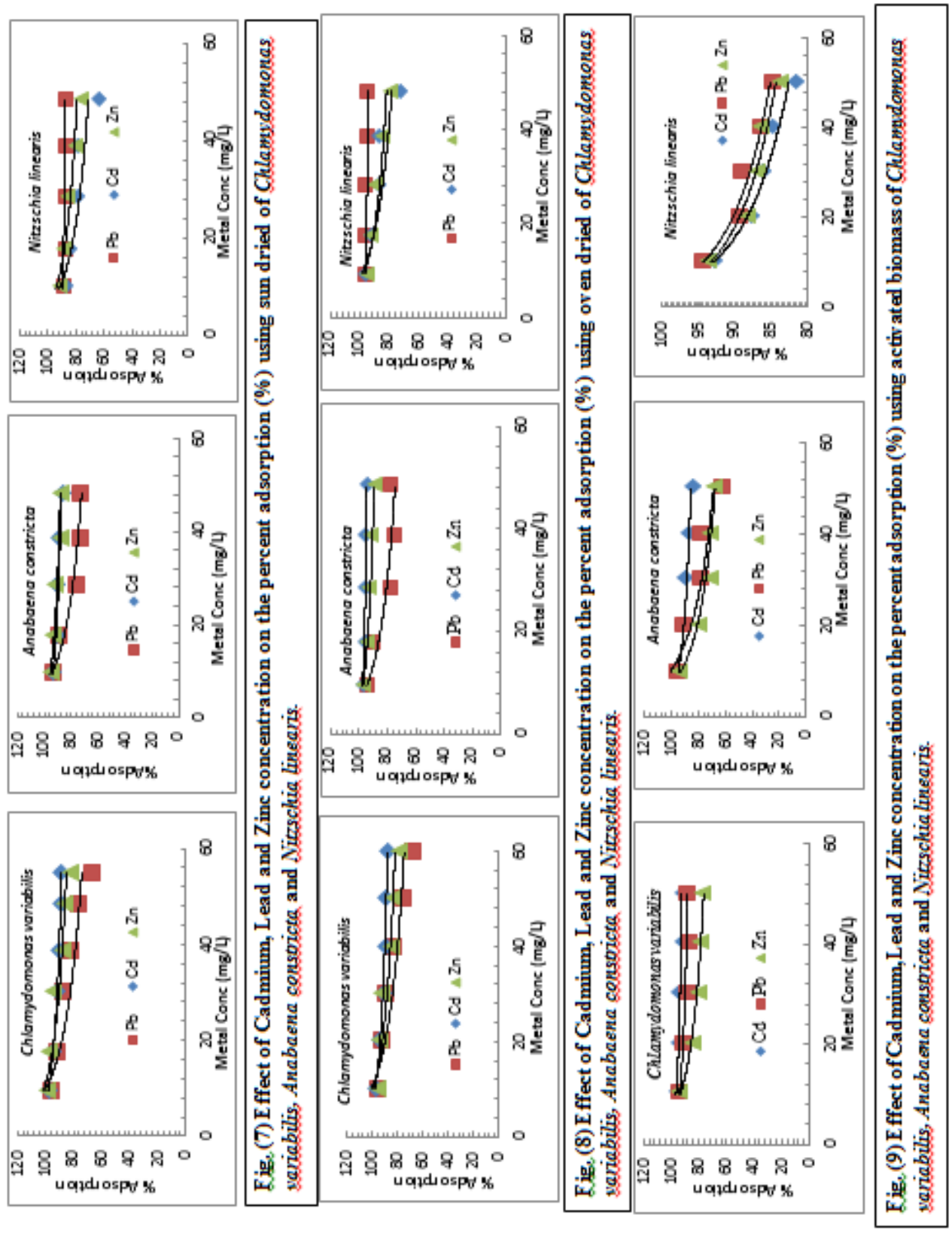

Egyptian J. of Phycol. Vol. 16, 2015 
In Nitzschia the percentage removals for $\mathrm{Cd}, \mathrm{Pb}$ and $\mathrm{Zn}$ ions were $93.0 \%$, $94.5 \%$ and $93.8 \%$ respectively. These removals were obtained at 9.3, 9 and 8.6 $\mathrm{mg} / \mathrm{L}$ for $\mathrm{Cd}, \mathrm{Pb}$ and $\mathrm{Zn}$ ions respectively (Fig. 9). Also the data show percentages adsorption decreased with increase in initial concentrations of the adsorbate which in agreement with Arıca et al., (2005) when used the Chlamydomonas reinhardtii activated with acid for chromium ion biosorption, they found that the biosorption decrease as the initial concentration of chromium ions increased.

Barange et al., (2014) recorded that maximum biosorption of $\mathrm{Pb}$ with green algal species corresponding to contact time was $131.6 \mathrm{mg} / \mathrm{g}(3 \mathrm{~h})$ and minimum was $28.72 \mathrm{mg} / \mathrm{g}(3 \mathrm{~h})$, while maximum for $\mathrm{Zn}$ was $43.43 \mathrm{mg} / \mathrm{g}(1 \mathrm{~h})$ and minimum was $1.37 \mathrm{mg} / \mathrm{g}(0.3 \mathrm{~h})$.

\section{Application of biosorption isotherms for different biomasses of isolated algae}

The experimental data of $\mathrm{Cd}, \mathrm{Pb}$, and $\mathrm{Zn}$ for different biomasses of the three isolated algae could better be described by the two isotherms where $\mathrm{R}^{2}$ is more than 0.9 .

Concerning the sun dried biomass, in Chlamydomonas the Langmuir maximum sorption capacity of algal biomass $\left(\mathrm{q}_{\max }\right)$ was found to be $31.25 \mathrm{mg} / \mathrm{g}$ for $\mathrm{Cd}, 24.15 \mathrm{mg} / \mathrm{g}$ for $\mathrm{Pb}$ and $24.4 \mathrm{mg} / \mathrm{g}$ for $\mathrm{Zn}$, and Freundlich constants $\left(\mathrm{K}_{\mathrm{f}}\right)$ were found to be 8.24 for $\mathrm{Cd}, 7.03$ for $\mathrm{Pb}$ and 10.11 for $\mathrm{Zn}$. Tüzün et al., (2005) reported that the $\left(\mathrm{q}_{\max }\right)$ for removal of $\mathrm{Cd}$ using Chlamydomonas reinhardtii was $42.7 \mathrm{mg} / \mathrm{g}$ at $\mathrm{pH} 6$ and equilibrium time $1 \mathrm{~h}$. The $\left(\mathrm{q}_{\max }\right)$ for Anabaena was found to be $34.7 \mathrm{mg} / \mathrm{g}$ for $\mathrm{Cd}, 14.9 \mathrm{mg} / \mathrm{g}$ for $\mathrm{Pb}$ and $31 \mathrm{mg} / \mathrm{g}$ for $\mathrm{Zn}$, and Freundlich constants $\left(\mathrm{K}_{\mathrm{f}}\right)$ were found to be 6.15 for $\mathrm{Cd}, 5.57$ for $\mathrm{Pb}$ and 7.29 for $\mathrm{Zn}$. In Nitzschia it was found that $\left(\mathrm{q}_{\max }\right) 20.8 \mathrm{mg} / \mathrm{g}$ for $\mathrm{Cd}, 74.6 \mathrm{mg} / \mathrm{g}$ for $\mathrm{Pb}$ and 25.6 $\mathrm{mg} / \mathrm{g}$ for $\mathrm{Zn}$ and Freundlich constants $\left(\mathbf{K}_{\mathbf{f}}\right)$ were found to be 7.1 for $\mathrm{Cd}, 4.2$ for $\mathrm{Pb}$ and 5.7 for $\mathrm{Zn}$ (Table 1). 
Table (1) Isotherm model parameters for sun dried algal biomass of Chlamydomonas variabilis, Anabaena constricta and Nitzschia linearis

\begin{tabular}{|l|c|c|c|c|c|c|c|c|c|}
\hline \multicolumn{1}{|c|}{ Algal isolates } & \multicolumn{2}{|c|}{ Chlamydomonas variabilis } & \multicolumn{3}{c|}{ Anabaena constricta } & \multicolumn{3}{c|}{ Nitzschia linearis } \\
\hline $\begin{array}{l}\text { Langmuir } \\
\text { constants }\end{array}$ & $\mathbf{C d}$ & $\mathbf{P b}$ & $\mathbf{Z n}$ & $\mathbf{C d}$ & $\mathbf{P b}$ & $\mathbf{Z n}$ & $\mathbf{C d}$ & $\mathbf{P b}$ & $\mathbf{Z n}$ \\
\hline $1 / \mathrm{q}_{\max }(\mathrm{g} / \mathrm{mg})$ & 0.032 & 0.0414 & 0.041 & 0.028 & 0.067 & 0.0323 & 0.048 & 0.0134 & 0.039 \\
\hline $\mathrm{q}_{\max }(\mathrm{mg} / \mathrm{g})$ & 31.25 & 24.15 & 24.4 & 34.7 & 14.9 & 31 & 20.8 & 74.6 & 25.6 \\
\hline $1 / \mathrm{bq}_{\max }$ & 0.086 & 0.117 & 0.076 & 0.132 & 0.116 & 0.095 & 0.085 & 0.227 & 0.141 \\
\hline $1 / \mathrm{b}$ & 2.68 & 2.82 & 1.85 & 4.58 & 1.73 & 2.9 & 1.7 & 16.9 & 3.6 \\
\hline $\mathrm{b} 1 / \mathrm{mg}$ & 0.37 & 0.354 & 0.54 & 0.218 & 0.577 & 0.34 & 0.56 & 0.059 & 0.27 \\
\hline $\mathrm{R}^{2}$ & 0.949 & 0.988 & 0.971 & 0.990 & 0.969 & 0.978 & 0.995 & 0.927 & 0.915 \\
\hline $\mathbf{F r e u n d l i c h}$ \\
constants
\end{tabular}

For oven dried biomass, the Langmuir maximum sorption capacity $\left(\mathrm{q}_{\max }\right)$ of Chlamydomonas was found to be $27.7 \mathrm{mg} / \mathrm{g}$ for $\mathrm{Cd}, 25 \mathrm{mg} / \mathrm{g}$ for $\mathrm{Pb}$ and $24.4 \mathrm{mg} / \mathrm{g}$ for $\mathrm{Zn}$, while $\left(\mathrm{K}_{\mathrm{f}}\right)$ was found to be 9.66 for $\mathrm{Cd}, 8.37$ for $\mathrm{Pb}$ and 5.99 $\mathrm{mg} / \mathrm{g}$ for $\mathrm{Zn}$. In Anabaena $\left(\mathrm{q}_{\max }\right.$ ) of algal biomass was found to be $38.4 \mathrm{mg} / \mathrm{g}$ for $\mathrm{Cd}, 15.4 \mathrm{mg} / \mathrm{g}$ for $\mathrm{Pb}$ and $29.4 \mathrm{mg} / \mathrm{g}$ for $\mathrm{Zn}$ whereas the $\left(\mathrm{K}_{\mathrm{f}}\right)$ was found to be 11.64 for $\mathrm{Cd}, 5.5$ for $\mathrm{Pb}$ and $8.61 \mathrm{mg} / \mathrm{g}$ for $\mathrm{Zn}$. In Nitzschia ( $\mathrm{q}_{\mathrm{max}}$ ) of algal biomass was found to be $20.8 \mathrm{mg} / \mathrm{g}$ for $\mathrm{Cd}, 50 \mathrm{mg} / \mathrm{g}$ for $\mathrm{Pb}$ and $18.8 \mathrm{mg} / \mathrm{g}$ for $\mathrm{Zn}$, where $\left(\mathrm{K}_{\mathrm{f}}\right)$ was found to be 7.1 for $\mathrm{Cd}, 10.4$ for $\mathrm{Pb}$ and $6.6 \mathrm{mg} / \mathrm{g}$ for $\mathrm{Zn}$ (Table 2). Matei et al., (2014) found that the adsorption capacity $\left(\mathrm{q}_{\max }\right)$ of dried biomass of green alga Spirogyra sp. with $\mathrm{Cd}$ ion was $22.5 \mathrm{mg} / \mathrm{g}$. Also Kumar et al., (2009) observed that, the adsorption capacity $\left(\mathrm{q}_{\max }\right)$ of the oven dried biomass of green algae, for $\mathrm{Pb}$ biosorbtion were 31.2, 29.4, 37.0 and $21.2 \mathrm{mg} / \mathrm{g}$ respectively. Arica et al., (2005) investigated the biosorption of $\mathrm{Cr}$ (VI) by heat treated Chlamydomonas reinhardtii. They found that $\left(\mathrm{q}_{\max }\right)$ equal to $30.2 \mathrm{mg} / \mathrm{g}$. A ksu and Dönmez (2006), used dried Chlorella vulgaris to achieve Cd removal as they found $\left(\mathrm{q}_{\max }\right)$ equal to $86 \mathrm{mg} / \mathrm{g}$ at $\mathrm{pH} 4 \mathrm{in} 24 \mathrm{~h}$, while Ferreira et al., (2011), used it to remove $\mathrm{Pb}$ and $\mathrm{Zn}$ and the $\left(\mathrm{q}_{\max }\right)$ equal 131.4 and $43.3 \mathrm{mg} / \mathrm{g}$ respectively. Gaur and Dhankhar (2009), when examined the removal of $\mathrm{Zn}$ ions from 
aqueous solution using oven dried biomass of Anabaena variabilis, they found that $\left(\mathrm{q}_{\max }\right)$ was $44.4 \mathrm{mg} / \mathrm{g}$. Also Abdel-Aty et al., (2013) found that, by using Anabaena sphaerica biomass $\left(\mathrm{K}_{\mathrm{f}}\right)$ were 15.3 for $\mathrm{Cd}$ and 28.28 for Pb. Similarly, Duygu and Bikem (2013) demonstrated that the oven dried biomass of Nitzschia closterium offers interesting possibility as a cation biosorbent with equilibrium sorption capacity $\left(\mathrm{q}_{\max }=81.45,81.73,86.04,87.94,116.72\right.$ and $130.08 \mathrm{mg} / \mathrm{g}$ for $\mathrm{Fe}^{3+}, \mathrm{Cr}^{6+}, \mathrm{Zn}^{2+}, \mathrm{Ni}^{2+}, \mathrm{Cd}^{2+}$ and $\mathrm{Pb}^{2+}$, respectively) and removal efficiency $(28.2,23.3,16.9,15.8,16.6,16.2 \%$, respectively).

Table (2) Isotherm model parameters for oven dried algal biomass of Chlamydomonas variabilis, Anabaena constricta and Nitzschia linearis

\begin{tabular}{|l|c|c|c|c|c|c|c|c|c|}
\hline \multicolumn{1}{|c|}{ Algal isolates } & \multicolumn{2}{|c|}{ Chlamydomonas variabilis } & \multicolumn{3}{c|}{ Anabaena constricta } & \multicolumn{3}{c|}{ Nitzschia linearis } \\
\hline $\begin{array}{l}\text { Langmuir } \\
\text { constants }\end{array}$ & $\mathbf{C d}$ & $\mathbf{P b}$ & $\mathbf{Z n}$ & $\mathbf{C d}$ & $\mathbf{P b}$ & $\mathbf{Z n}$ & $\mathbf{C d}$ & $\mathbf{P b}$ & $\mathbf{Z n}$ \\
\hline $1 / \mathrm{q}_{\max }(\mathrm{g} / \mathrm{mg})$ & 0.036 & 0.040 & 0.041 & 0.026 & 0.65 & 0.034 & 0.048 & 0.02 & 0.053 \\
\hline $\mathrm{q}_{\max }(\mathrm{mg} / \mathrm{g})$ & 27.7 & 25 & 24.4 & 38.4 & 15.4 & 29.4 & 20.8 & 50 & 18.8 \\
\hline $1 / \mathrm{bq}_{\max }$ & 0.207 & 0.106 & 0.076 & 0.053 & 0.110 & 0.071 & 0.085 & 0.072 & 0.087 \\
\hline $1 / \mathrm{b}$ & 5.75 & 2.65 & 1.85 & 2.04 & 1.7 & 2.08 & 1.77 & 3.6 & 1.64 \\
\hline $\mathrm{b} 1 / \mathrm{mg}$ & 0.173 & 0.377 & 0.540 & 0.5 & 0.6 & 0.48 & 0.56 & 0.27 & 0.61 \\
\hline $\mathrm{R}^{2}$ & 0.918 & 0.987 & 0.980 & 0.924 & 0.972 & 0.974 & 0.996 & 0.852 & 0.999 \\
\hline $\begin{array}{l}\text { Freundlich } \\
\text { constants }\end{array}$ & & & & & & & & & \\
\hline $\mathbf{K}_{\mathbf{f}}$ & 9.66 & 8.37 & 5.99 & 11.64 & 5.5 & 8.61 & 7.1 & 10.4 & 6.6 \\
\hline $\mathbf{N}$ & 2.14 & 1.74 & 4.29 & 1.55 & 2.3 & 1.77 & 2.4 & 1.33 & 2.16 \\
\hline $\mathbf{R}^{2}$ & 0.987 & 0.973 & 0.970 & 0.984 & 0.964 & 0.989 & 0.947 & 0.995 & 0.961 \\
\hline
\end{tabular}

Regarding the activated biomass (Table 3), In Chlamydomonas $\left(\mathrm{q}_{\max }\right)$ was found to be $38.5 \mathrm{mg} / \mathrm{g}$ for $\mathrm{Cd}, 33.3 \mathrm{mg} / \mathrm{g}$ for $\mathrm{Pb}$, and $17.5 \mathrm{mg} / \mathrm{g}$ for $\mathrm{Zn}$ whereas $\left(\mathrm{K}_{\mathrm{f}}\right)$ and $(\mathrm{n})$ were found to be 9.1 and 1.51 for $\mathrm{Cd}, 6.45$ and 1.45 for $\mathrm{Pb}$; and 5.41 and 2.1 for $\mathrm{Zn}$ respectively. In Anabaena $\left(\mathrm{q}_{\max }\right.$ ) was found to be 32.2 $\mathrm{mg} / \mathrm{g}$ for $\mathrm{Cd}, 14.9 \mathrm{mg} / \mathrm{g}$ for $\mathrm{Pb}$ and $15.6 \mathrm{mg} / \mathrm{g}$ for $\mathrm{Zn}$, while $\left(\mathrm{K}_{\mathrm{f}}\right)$ was found to be 6.5 for $\mathrm{Cd}, 6.33$ for $\mathrm{Pb}$ and 5.0 for $\mathrm{Zn}$. In Nitzschia $\left(\mathrm{q}_{\max }\right)$ was found to be 33.3 $\mathrm{mg} / \mathrm{g}$ for $\mathrm{Cd}, 28.6 \mathrm{mg} / \mathrm{g}$ for $\mathrm{Pb}$ and $25.6 \mathrm{mg} / \mathrm{g}$ for $\mathrm{Zn}$ and $\left(\mathrm{K}_{\mathrm{f}}\right) 8.7 \mathrm{mg} / \mathrm{g}$ for $\mathrm{Cd}$, $6.12 \mathrm{mg} / \mathrm{g}$ for $\mathrm{Pb}$ and $5.7 \mathrm{mg} / \mathrm{g}$ for $\mathrm{Zn}$. Arica et al., (2005) found that $\left(\mathrm{q}_{\max }\right)$ and 
(n) were $25.6 \mathrm{mg} / \mathrm{g}$ and 2.18 respectively for Chlamydomonas reinhardtii activated by acid.

Table (3) Isotherm model parameters for activated algal biomass of Chlamydomonas variabilis, Anabaena constricta and Nitzschia linearis

\begin{tabular}{|l|c|c|c|c|c|c|c|c|c|}
\hline \multicolumn{1}{|c|}{ Algal isolates } & \multicolumn{3}{|c|}{ Chlamydomonas variabilis } & \multicolumn{3}{c|}{ Anabaena constricta } & \multicolumn{3}{c|}{ Nitzschia linearis } \\
\hline $\begin{array}{l}\text { Langmuir } \\
\text { constants }\end{array}$ & $\mathbf{C d}$ & $\mathbf{P b}$ & $\mathbf{Z n}$ & $\mathbf{C d}$ & $\mathbf{P b}$ & $\mathbf{Z n}$ & $\mathbf{C d}$ & $\mathbf{P b}$ & $\mathbf{Z n}$ \\
\hline $1 / \mathrm{q}_{\max }(\mathrm{g} / \mathrm{mg})$ & 0.026 & 0.03 & 0.057 & 0.031 & 0.067 & 0.064 & 0.030 & 0.035 & 0.039 \\
\hline $\mathrm{q}_{\max }(\mathrm{mg} / \mathrm{g})$ & 38.5 & 33.3 & 17.5 & 32.2 & 14.9 & 15.6 & 33.3 & 28.6 & 25.6 \\
\hline $1 / \mathrm{bq} \max$ & 0.077 & 0.120 & 0.140 & 0.127 & 0.09 & 0.185 & 0.172 & 0.135 & 0.141 \\
\hline $1 / \mathrm{b}$ & 2.96 & 4 & 2.45 & 4.1 & 1.3 & 2.9 & 5.7 & 3.8 & 3.6 \\
\hline $\mathrm{b} 1 / \mathrm{mg}$ & 0.337 & 0.250 & 0.407 & 0.24 & 0.74 & 0.34 & 1.74 & 2.6 & 0.27 \\
\hline $\mathrm{R}^{2}$ & 0.944 & 0.955 & 0.922 & 0.944 & 0.988 & 0.910 & 0.918 & 0.905 & 0.915 \\
\hline $\begin{array}{l}\text { Freundlich } \\
\text { constants }\end{array}$ & & & & & & & & & \\
\hline $\mathbf{K}_{\mathbf{f}}$ & 9.1 & 6.45 & 5.41 & 6.5 & 6.33 & 5.0 & 8.7 & 6.12 & 5.7 \\
\hline $\mathbf{N}$ & 1.51 & 1.45 & 2.1 & 1.7 & 3.2 & 2.7 & 1.52 & 1.73 & 1.72 \\
\hline $\mathbf{R}^{2}$ & 0.994 & 0.994 & 0.971 & 0.966 & 0.961 & 0.970 & 0.988 & 0.986 & 0.992 \\
\hline
\end{tabular}

\section{C) Metal recovery}

Regarding sun dried biomasses of algae species, it was found that the percentages recovery by Chlamydomonas were at the first run $\mathrm{Zn}(85.8 \%)=\mathrm{Pb}$ $(85.8 \%)>\mathrm{Cd}(83.3 \%)$ but at the second run decrease to $\mathrm{Cd}(43.5 \%)>\mathrm{Zn}(41.8 \%)$ $>\mathrm{Pb}(40 \%)$. In Anabaena the percentages of recovery were $\mathrm{Cd}(52.6 \%)>\mathrm{Pb}(40$ $\%)>\mathrm{Zn}(39.42 \%)$ and at the second run the percentages were $\mathrm{Cd}(53.7 \%)>\mathrm{Zn}$ $(45.8 \%)>\mathrm{Pb}(38.4 \%)$. In Nitzschia according to the percentages recovery at the heavy metal can arranged in descending manner at first run as $\mathrm{Cd}(54.1 \%)>\mathrm{Pb}$ $(45.3 \%)>\mathrm{Zn}(44.4 \%)$ but at the second run the order was $\mathrm{Pb}(54.5 \%)>\mathrm{Zn}$ $(50.9 \%)>\mathrm{Cd}(48.8 \%)$.

In oven dried biomasses, the percentages recovery by Chlamydomonas biomass at the first run were $\mathrm{Zn}(88.4 \%)>\mathrm{Cd}(87.3 \%)>\mathrm{Pb}(84.3 \%)$ and at the second run decreased to be $\mathrm{Cd}(43.9 \%)>\mathrm{Zn}(42.8 \%)>\mathrm{Pb}(41.5 \%)$. In Anabaena the percentages of recovery at the first run were $\mathrm{Zn}(51.9 \%)>\mathrm{Cd}(46.3 \%)>\mathrm{Pb}$ $(43.3 \%)$ and decreased at the second run to be $\mathrm{Zn}(50.7 \%)>\mathrm{Cd}(49.09 \%)>\mathrm{Pb}$ 
(40\%). The three metals can be arranged according to percentages recovery in Nitzschia at the first run as $\mathrm{Cd}(56.3 \%)>\mathrm{Pb}(46 \%)>\mathrm{Zn}(44.8 \%)$ and at the second run the order was $\mathrm{Pb}(63.7 \%)>\mathrm{Zn}(61.9 \%)>\mathrm{Cd}(50.7 \%)$.

In case of activated biomasses, the percentages of recovery in Chlamydomonas at the first run were arranged as $\mathrm{Cd}(76.6 \%)>\mathrm{Zn}(69.7 \%)>\mathrm{Pb}$ $(65.4 \%)$ and at the second run the order was $\mathrm{Zn}(44.1 \%)>\mathrm{Cd}(43.6 \%)>\mathrm{Pb}$ (40.8\%). Regarding the percentages of recovery in A. constricta while the percentages of recovery were arranged as $\mathrm{Cd}(58.6 \%)>\mathrm{Zn}(47.03 \%)>\mathrm{Pb}$ $(46.2 \%)$ at the first run and $\mathrm{Zn}(56.7 \%)>\mathrm{Pb}(56.6 \%)>\mathrm{Cd}(52.9 \%)$ at the second run. Similarly in Nitzschia linearis the percentages of recovery were Cd $(57.8 \%)$ $>\mathrm{Pb}(46.1 \%)>\mathrm{Zn}(44.8 \%)$ at the first run and $\mathrm{Cd}(69.3 \%)>\mathrm{Pb}(52 \%)>\mathrm{Zn}$ (47.3\%) at the second run._Gupta and Rastogi (2009), found that acid-treated green alga Oedogonium hatei could be regenerated from metal, with up to $75 \%$ recovery. Deng $\boldsymbol{e t}$ al., (2007) investigate the desorption of lead from waste water by green algae Cladophora fascicularis, they found that recovery with $0.1 \mathrm{~mol} / \mathrm{L}$ $\mathrm{HNO}_{3}$ was $85 \%$. Gupta and Rastogi (2009), found that acid-treated green alga Oedogonium hatei could be regenerated from metal, with up to $75 \%$ recovery.

By comparing the efficiency of the different biosorbents for metal removal and recovery experiments, it is evident from data predicted that: no clear differences between sun dried, oven dried, and activated biosorbents (Table 4, 5).

\section{Conclusion}

The results of this investigation conclude that, there are no clear variations in biosorption of cadmium, lead and zinc by $C$. variabilis, A. constricta and $N$. linearis; also there are obvious similarities between sun dried, oven dried and activated biosorbents of different algal isolates in metal removal. Subsequently, it was recommended using sun dried algae as low cost biosorbent for metals removal. 


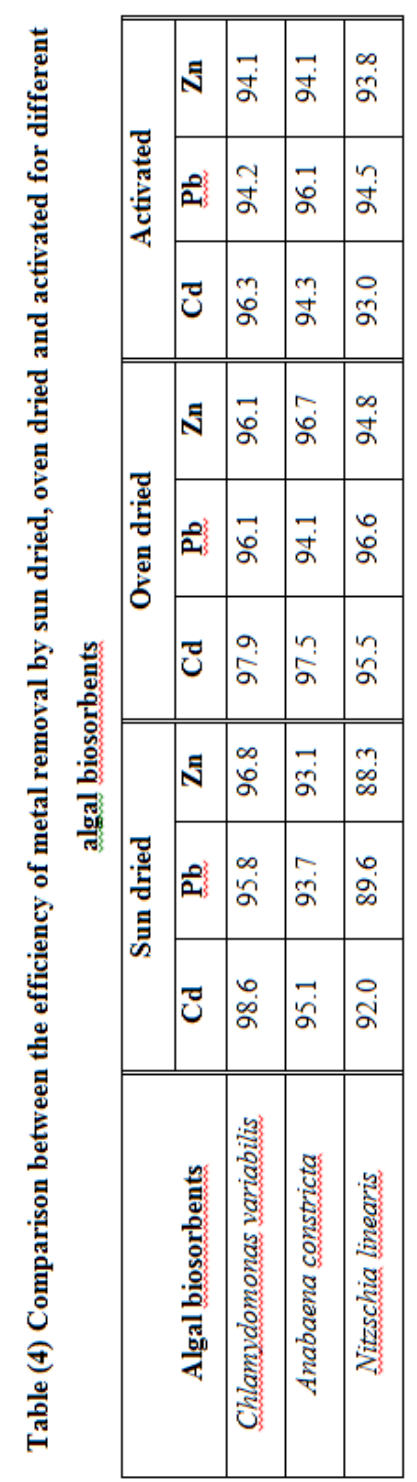

Egyptian J. of Phycol. Vol. 16, 2015

\begin{tabular}{|c|c|c|c|c|c|}
\hline \multirow{6}{*}{ 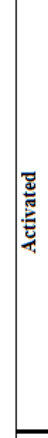 } & & & $\vec{\ddagger}$ & 品 & $\tilde{q}$ \\
\hline & 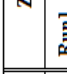 & 基 & B̀ & $\begin{array}{l}\stackrel{m}{a} \\
\stackrel{y}{+}\end{array}$ & $\begin{array}{l}\infty \\
+ \\
\end{array}$ \\
\hline & & 嵁 & $\begin{array}{c}\infty \\
\dot{+} \\
\dot{o}\end{array}$ & $\begin{array}{l}\text { 吕 } \\
\text { in }\end{array}$ & $\approx$ \\
\hline & 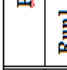 & 基 & 落 & ช̊ำ & $\vec{b}$ \\
\hline & & & $\stackrel{\circ}{\check{q}}$ & ฉે & $\frac{m}{8}$ \\
\hline & 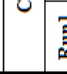 & 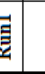 & $\stackrel{\circ}{\circ}$ & $\begin{array}{l} \\
\stackrel{\infty}{\circ} \\
i n\end{array}$ & $\stackrel{\infty}{\check{n}}$ \\
\hline \multirow{6}{*}{ 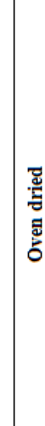 } & & $\frac{1}{4}$ & $\stackrel{\infty}{q}$ & ì & $\stackrel{9}{b}$ \\
\hline & 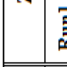 & 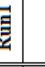 & $\begin{array}{l}+ \\
\infty \\
\infty\end{array}$ & in & $\stackrel{\infty}{+}$ \\
\hline & & $\frac{1}{4}$ & $\stackrel{n}{7}$ & o & $\overline{8}$ \\
\hline & & 焉 & $\underset{\infty}{m}$ & $\ddot{m}$ & o \\
\hline & $=$ & 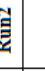 & gे & $\begin{array}{l}\stackrel{8}{\circ} \\
\dot{q}\end{array}$ & in \\
\hline & 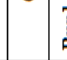 & 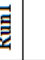 & $\stackrel{m}{\infty}$ & m̧a & i. \\
\hline \multirow{6}{*}{ 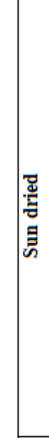 } & & 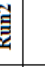 & $\begin{array}{l}\infty \\
\vec{f}\end{array}$ & $\begin{array}{l}\infty \\
⿱ 亠 乂 \\
q\end{array}$ & $\begin{array}{l}8 \\
\text { D. } \\
\end{array}$ \\
\hline & & 基 & 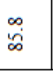 & $\begin{array}{l}\text { f } \\
\text { d. }\end{array}$ & $\begin{array}{l}+ \\
\\
\end{array}$ \\
\hline & $\therefore$ & $\frac{1}{4}$ & 우 & 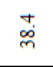 & 覓 \\
\hline & & 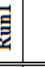 & $\begin{array}{l}\infty \\
\vdots \\
\vdots\end{array}$ & q & $\hat{q}$ \\
\hline & & 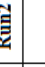 & 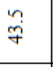 & $\hat{n}$ & $\underset{\substack{\infty \\
\dot{q}}}{\infty}$ \\
\hline & & 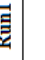 & $\stackrel{\infty}{\infty}$ & ๙ & $\vec{f}$ \\
\hline & & & 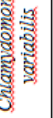 & 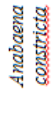 & 8 \\
\hline
\end{tabular}




\section{References}

Abdel-Aty, A.M.; Nabila, S. A.; Hany, H.A. and Rizka, K.A. (2013). Biosorption of cadmium and lead from aqueous solution by fresh water alga Anabaena sphaerica biomass. J. Adv. Res., 4: 367-374.

Aksu, Z. and Dönmez, G. (2006). Binary biosorption of cadmium (II) and nickel(II) onto dried Chlorella vulgaris: Co-ion effect on monocomponent isotherm parameters. Process Biochem., 41: 860-868.

Anayurt, R.A.; Sari, A. and Tuzen, M. (2009). Equilibrium, thermodynamic and kinetic studies on biosorption of $\mathrm{Pb}$ (II) and $\mathrm{Cd}(\mathrm{II})$ from aqueous solution by macrofungus (Lactarius scrobiculatus) biomass. Chem. Engine. J., 151: 255-261.

Arıca, Y. M.; Tüzün, I.; Yalçın, E.; İnce, Ö. and Bayramoğlu, G. (2005). Utilisation of native, heat and acid-treated microalgae Chlamydomonas reinhardtii preparations for biosorption of $\mathrm{Cr}$ (VI) ions. Process Biochem., 40: 2351-2358.

Atolaiye, B.O., Babalola, J.O., Adebayo, M.A. and Aremu, M.O. (2009). Equilibrium modeling and $\mathrm{pH}$-dependence of the adsorption capacity of Vitex doniana leaf for metal ions in aqueous solutions. Afr. J. Biotech., 8: 507-514.

Babel, S. and Kurniawan, A.T. (2003). Low-cost adsorbents for heavy metals uptake from contaminated water: A review. J. Hazard. Mater., 97: 219243.

Bakatula, E.N.; Cukrowska, E.M.; Weiersbye, I.M.; Mihaly-Cozmuta, L.; Peter, A. and Tutu, H. (2014). Biosorption of trace elements from aqueous systems in gold mining sites by the filamentous green algae (Oedogonium sp.). J. Geochemical Exploration, 144: 492-503.

Barange, M.; Srivastava, A.; Srivastava, J.K. and Palsania, J. (2014). Biosorption of Heavy Metals from Wastewater by Using Microalgae. Inter. J. of Chem. and Physi. Sci., 3: 67 -81.

Bulgariu, L. and Bulgariu, D. (2014). Enhancing Biosorption Characteristics of Marine Green Algae (Ulva lactuca) for Heavy Metals Removal by Alkaline Treatment. J. Bioproces. Biotechniq., 4:1. 
Cesar, T.T.R. and Marco, Z.A.A. (2004). Biosorption of heavy metals using rice milling by-products: characterisation and application for removal of metals from aqueous effluents. Chemosphere, 54: 987-995.

Chinedu, J.O.; Charles, M. and Onyema, M. A. (2012). Equilibrium, Kinetic, Thermodynamic and Thermal Stability Studies on Sorption of Ni (II) ions from Aqueous Solution using Dead Biomass of Fresh Water Green Alga Cosmarium panamense. Der Chemica Sinica, 3 (1): 38-51.

Christobel, J. and Lipton, A.P. (2105). Evaluation of macroalgal biomass for removal of heavy metal Arsenic (As) from aqueous solution. Inter. J. Appli. or Innov. Engine. \& Manag. (IJAIEM), 4: 94-104.

Cohn, S. A.; Farrell, J. F.; Munro, D. J.; Ragland, R. L.; Weitzell, R. E. J. and Wibisono, B. L. (2003). The effect of temperature and mixed species composition on diatom motility and adhesion. Diatom Res., 18: 225-43.

Deng, L.; Yingying, S.; Hua, S.; Wang, X. and Zhu, X. (2007). Sorption and desorption of lead (II) from wastewater by green algae Cladophora fascicularis. J. Hazard. Mater., 143: 220-225.

Duygu, O. and Bikem, Ö. (2013). Characterization of Heavy Metal Biosorption from Aqueous Solutions with Nitzschia closterium Biomass. The ICOEST Conf. (Part 2) Cappadocia, 96-107.

Eggen, M. (2012). Uptake and biological response to zinc by the Diatom Thalassiosira pseudonana. Norwegian University of Science and Technology. Department of Biotechnology.

El-Sikaily, A.; El Nemr, A. and Khaled, A. (2011). Copper sorption onto dried red alga Pterocladia capillacea and its activated carbon. Chem. Engine. J., 168: 707-714.

Errasquin, E.L. and Vazquez, C. (2003). Tolerance and uptake of heavy metals by Trichoderma atroviride isolated from sludge. Chemosphere, 50: 137143.

Ferreira, L.S.; Rodriguesa, M.S.; Monteiro de Carvalhoa, J.C.; Lodi, A.; Finocchio, E.; Perego, P. and Converti, A. (2011). Adsorption of Ni2+, $\mathrm{Zn} 2+$ and $\mathrm{Pb} 2+$ onto dry biomass of Arthrospira (Spirulina) platensis and Chlorella vulgaris. I. Single metal systems. Chem. Engine. J., 173: 326333. 
Figueira, M.; Volesky, B.; Azarian, K. and Ciminelli, V.S. (1999). Multimetal biosorption in a column using Sargassum biomass," Biohydrometallurgy and the environment toward the mining of the 21 st century (part $\mathrm{b}$ ): International biohydrometallurgy symposium proceedings, R. Amils and A. Ballester (Editors), Elsevier Science, Amsterdam, the Netherlands, 503 -512.

Gaur, N. and Dhankhar, R. (2009). Removal of $\mathrm{Zn}^{+2}$ ions from aqueous solution using Anabaena variabilis: Equilibrium and Kinetic studies .Int. J. Environ. Res., 3: 605-616.

Geitler, L. (1932). Cyanophyceae. In L. Rabenhorst (Ed.).

Guibaud, G.; Tixier, N.; Bouju, A. and Baudu, M. (2003). Relation between extracellular polymers composition and its ability to complex $\mathrm{Cd}, \mathrm{Cu}$ and $\mathrm{Pb}$. Chemosphere, 52: 1701-1710.

Gupta, V. K. and Rastogi, A. (2008). Biosorption of lead from aqueous solutions by nonliving algal biomass Oedogenium sp. and Nostoc sp. - a comparative study. Colloids Surf. B: Biointerfaces.; 64 (2): 170-178.

Gupta V.K. and Rastogi, A. (2009). Biosorption of hexavalent chromium by raw and acid-treated green alga Oedogonium hatei from aqueous solutions. $J$. Hazard. Mater., 163: 396-402.

Gupta V.K.; Rastogi, A.; Saini, V.K. and Jain, N. (2006). Bisorption of copper (II) from aqueous solutions by algae Spirogyra species. J. Colloid Interface Sci., 296 (1): 53-60.

Hawari, A.H. and Mulligan, C.N. (2006). Heavy metals uptake mechanisms in a fixed-bed column by calcium-treated anaerobic biomass. Process Biochem., 41: 187-198.

Huang, J.; Liu, Y.; Jin, Q.; Wang, X. and Yang, J. (2007). Adsorption studies of a water soluble dye, Reactive Red MF-3B, using sonication-surfactantmodified attapulgite clay. J. Hazard. Mater., 143(1-2): 541-548.

Hustedt, F. (1976). Bacillariophyta (Diatomaceae). Otto Koeltz Science Publishers W-Germany.

Jeyakumar, R.P.S. and Chandrasekaran, A.V. (2014). Adsorption of lead (II) ions by activated carbons prepared from marine green algae: Equilibrium and kinetics studies. Inter. J. Indust. Chem., 5:2. 
Karthikeyan, S.; Balasubramanian, R. and Lyer, C. S. P. (2007). Evaluation of the marine alga Ulva fasciata and Sargassum sp. for the biosorption of $\mathrm{Cu}$ (II) from aqueous solution. Bioresource Techn., 98: 452-455.

Komárek, J. and Fott, B. (1983). Chlorophyceae (Grünalgen), Ordnung Chlorococcales In: Huber-Pestalozzi G. (Ed.): Das Phytoplankton des Süsswassers. Die Binnengew ässer 16, 7/1: 1-1044, Schweizerbart Verlag, Stuttgart.

Kumar, K.S.; Dahms, H.U.; Won, E.J.; Lee, J.S. and Shin, K.H. (2015). Microalgae-A promising tool for heavy metal remediation. Ecotoxicology and Environmental Safety, 113: 329-352.

Kumar, R.; Singh, R.; Kumar, N.; Bishnoi, K. and Bishnoi, N.R. (2009). Response surface methodology approach for optimization of biosorption process for removal of $\mathrm{Cr}(\mathrm{VI}), \mathrm{Ni}(\mathrm{II})$ and $\mathrm{Zn}$ (II) ions by immobilized bacterial biomass sp. Bacillus brevis, Chem. Eng. J., 146: 401-407 .

Matei, G.M.; Kiptoo, J.K.; Oyaro, N.K. and Onditi, A.O. (2014). Biosorption of selected heavy metals by the biomass of the green alga Spirogyra sp. Physics, Chem. and Techn., 12 (1): 1 - 15.

Monteiro, C.M.; Castro, P.M.L. and Malcata, F.X. (2012). Metal uptake by microalga: underlying mechanisms and practical applications. Biotechnol.Prog., 28(2): 299-311.

Poulsen, N.; Berne, C.; Spain, J. and Kröger, N. (2007). Silica Immobilization of an enzyme through genetic engineering of the diatom Thalassiosira pseudonana. Angewandte Chemie, 46: 1843-1846.

Priyadarshani, I.; Sahu, D. and Rath, B. (2011). Microalgal bioremediation: current practices and perspectives. J. Biochem. Tech., 3: 299-304.

Romera, E.; González, F.; Ballester, A.; Blázquez, M.L. and Muñoz, J.A. (2007). Comparative study of biosorption of heavy metals using different types of algae. Bioresource Technology, 98: 3344-3353.

Sari, A. and Tuzen, M. (2008). Biosorption of cadmium (II) from aqueous solution by red algae (Ceramium virgatum): Equilibrium, kinetic and thermodynamic studies. J. Hazard. Mater., 157: 448-454. 
Sethunathan, N.; Megharaj, M.; Smith, L.; Kamaludeen, S.P.B.; Avudainayagam, S. and Naidu, R. (2005). Microbial role in the failure of natural attenuation of chromium (VI) in long-term tannery waste contaminated soil. Agriculture Ecosystems \& Environment, 105: 657661.

Sharma, M.; Kaushik, A. and Kaushik, C.P. (2011). Sequestration of Co (II) from aqueous solution using immobilized biomass of Nostoc linckia waste from a hydrogen bioreactor. Desalination, 276: 408-415.

Sheng, G.; Wang, S.; Hua, J.; Lua, Y.; Lia, J.; Dongc, Y. and Wanga, X. (2009). Adsorption of $\mathrm{Pb}$ (II) on diatomite as affected via aqueous solution chemistry and temperature. Colloids and Surfaces A: Physicochemical and Engineering Aspects, 339 (1-3): 159-166.

Staley, J.T. (1989). Bergey's Manual of Systematic Bacteriology, Williams \& Wilkins Co., Baltimore, MD, 1718-1720.

Stanier, R.Y., Kunisawa, M.M., and Cohn- Bazire, G. (1971). Purification and properties of unicellular blue green algae (order chroococcales). Bacteriology review, 35: 171-201.

Tüzün, I., Bayramoğlu, G., Yalçın, E., Başaran, G., Çelik, G. and Arıca, M.Y. (2005). Equilibrium and kinetic studies on biosorption of $\mathrm{Hg}(\mathrm{II}), \mathrm{Cd}(\mathrm{II})$ and $\mathrm{Pb}(\mathrm{II})$ ions onto microalgae Chlamydomonas reinhardtii. J. Environ. Manag., 77: 85-92.

Vieira, D.M.; da Costa, A.C.C.; Henriques, C.A.; Cardoso, V.L. and de Franca, F.P. (2007). Biosorption of lead by the brown seaweed Sargassum filipendula - batch and continuous pilot studies. Electr. J. Biotechnol.. 10: 368-375.

Wang, J.L. and Chen, C. (2009). Biosorbents for heavy metals removal and their future a review. Biotechnol. Adv., 27: 195-226.

Wang, X.J.; Chen, L.; Xia, S.Q.; Zhao, J.F.; Chovelon, J. and Renault, N.J. (2006). Biosorption of $\mathrm{Cu}$ (II) and $\mathrm{Pb}$ (II) from aqueous solutions by dried activated sludge. Miner Eng., 19: 968-971.

Yadanaparthi, S.K.R.; Graybill, D. and Von Wandruzska, R. (2009). Adsorbents for the removal of arsenic, cadmium and lead from contaminated waters. J. Hazard. Mater., 171: 1-15. 
Yalçın, E.; Çavuşoğlu, K. and Kınalığlu, K. (2010). Biosorption of $\mathrm{Cu} 2+$ and $\mathrm{Zn} 2+$ by raw and autoclaved Rocella phycopsis. Journal of Environmental Sciences, 22: 367-373.

Yang, C.P.; Wang, J.Q.; Lei, M.; Xie, G.X.; Zeng, G.M. and Luo, S.L. (2010). Biosorption of zinc (II) from aqueous solution by dried activated sludge. J. Environ. Sci., 22: 675-680.

Yu, Y.; Addai-Mensah, J. and Losic, D. (2012). Functionalized diatom silica microparticles for removal of mercury ions. Sci. Technol. Adv. Mater., 13: 11.

\section{دراسة مقارنة عن الادمصاص الحيوي والامتزاز لثثلاث معادن ثقيلة سامة منتخبة باستخدام بعض أنواع من الطحالب الاقيقة}

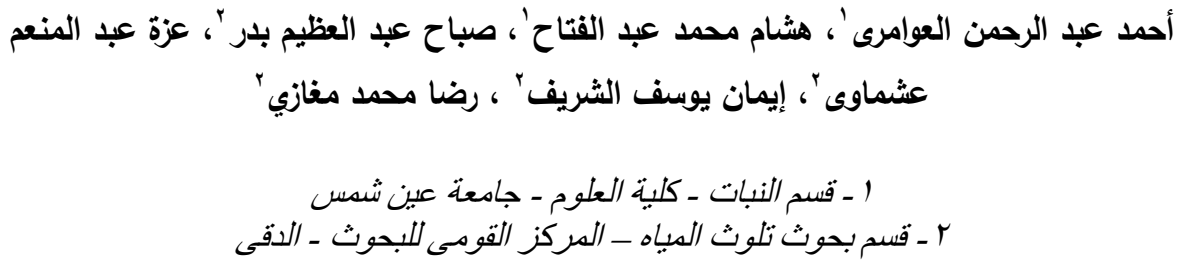

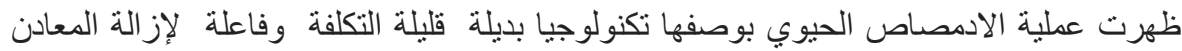

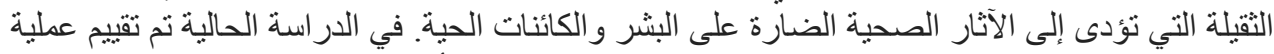

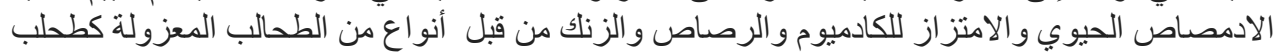
Nitzschia وطلب Chlamydomonas variabilis linearis

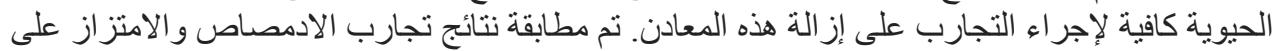

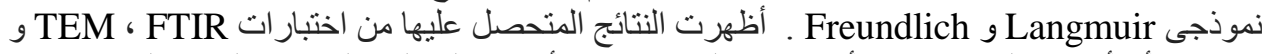

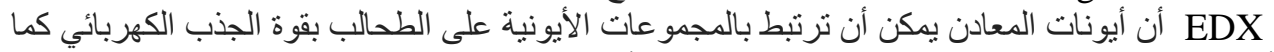

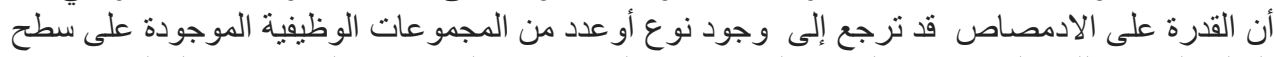

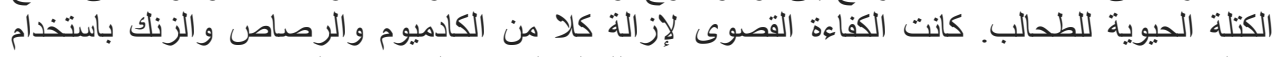

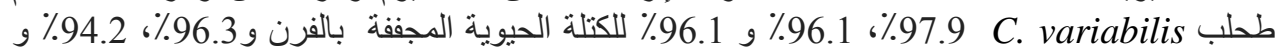

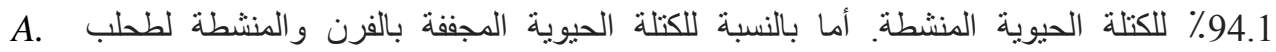
constricta

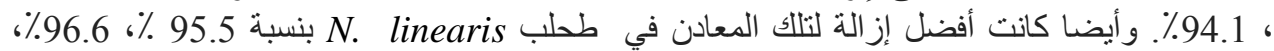




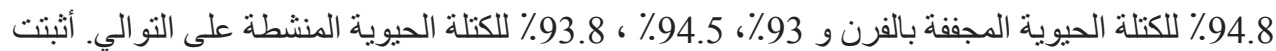

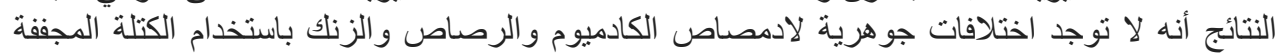

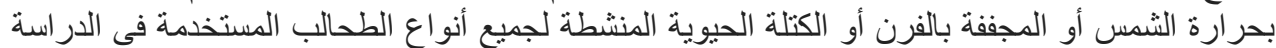
لذا يفضل استخدام الكتلة المجفقة بحر ارة الثمس لانخفاض تكلفتها فى عملية إز الة المعادن. 